\title{
Prevalence of tooth loss and associated factors in institutionalized adolescents: a cross-sectional study
}

\author{
Prevalência de perda dentária e fatores associados em adolescentes \\ institucionalizados: um estudo transversal
}

\author{
Maísa Casarin (https://orcid.org/0000-0002-3750-5091) ${ }^{1}$ \\ Wagner da Silva Nolasco (https://orcid.org/0000-0002-3560-3122) ${ }^{2}$ \\ Paulo Roberto Grafitti Colussi (https://orcid.org/0000-0002-9351-6959) ${ }^{3}$ \\ Carla Cioato Piardi (https://orcid.org/0000-0001-6040-8153) 4 \\ Patricia Weidlich (https://orcid.org/0000-0003-2013-8229) ${ }^{4}$ \\ Cassiano Kuchenbecker Rösing (https://orcid.org/0000-0002-8499-5759) ${ }^{4}$ \\ Francisco Wilker Mustafa Gomez Muniz (https://orcid.org/0000-0002-3945-1752) ${ }^{1}$
}

\footnotetext{
${ }^{1}$ Departamento de Periodontologia,

Faculdade de Odontologia, Universidade Federal Pelotas (UFPel). R. Gonçalves Chaves 457, Centro. 96015560 Pelotas RS Brasil. maisa.66@hotmail.com ${ }^{2}$ Faculdade de Odontologia, UFPel. Pelotas RS Brasil. ${ }^{3}$ Departamento de Periodontologia, Faculdade de Odontologia, Universidade de Passo Fundo. Passo Fundo RS Brasil.

${ }^{4}$ Departamento de Periodontologia, Faculdade de Odontologia, Universidade Federal do Rio Grande do Sul. Porto Alegre RS Brasil.
}

\begin{abstract}
This study aimed to assess the prevalence of tooth loss and associated factors in institutionalized adolescents. This cross-sectional study included 68 male adolescents incarcerated from Socio-Educational Assistance Center (CASE) aged between 15 and 19 years. Questionnaires were applied individually to assess sociodemographical, economical, medical, behavioral and oral health self-perception variables. All present teeth were evaluated by Decay, Missing, Filling (DMF) Index. The prevalence of tooth loss was analyzed in individuals with $\geq 1$ tooth loss. Associations between tooth loss and exposure variables studied were analyzed by Poisson Regression with robust variance estimation. The prevalence of tooth loss was $47.06 \%$. First molars in the mandible and maxilla and central incisor in the maxilla were the most absent teeth. In the multivariate model, number of decayed teeth, and those that reported daily use of medication were associated with higher tooth loss. Besides, tooth loss was associated with decayed tooth and daily use of medication. Oral health promotion and treatment should be implemented in these institutions to reduce the prevalence of dental loss in these adolescents.
\end{abstract}

Key words Tooth loss, Dental Caries, Teenagers, Oral Health
Resumo Esse estudo objetivou avaliar a prevalência de perda dentária e fatores associados em adolescentes institucionalizados. Esse estudo transversal incluiu 68 adolescentes do sexo masculino de um Centro de Atendimento Socioeducativo (CASE) com idades entre 15 e 19 anos. Questionários estruturados foram aplicados individualmente para acessar variáveis sociodemográficas, econômicas, médicas, comportamentais e autopercepção de saúde bucal. Todos os dentes presentes foram avaliados pelo Indice de dentes Cariados, Perdidos e Obturados (CPOD). A prevalência de perda dentária foi analisada em indivíduos com $\geq 1$ dente perdido. Associações entre perda dentária e variáveis de exposição foram analisadas por regressão de Poisson com estimativa de variância robusta. A prevalência de perda dentária foi 47,06\%. Primeiros molares na mandíbula e maxila e incisivos centrais na maxila foram os dentes mais ausentes. No modelo multivariado, número de dentes cariados esteve associado com perda dentária, e aqueles que faziam uso diário de medicações foram associados a maior perda dentária. Além disso, perda dentária foi associada com cárie dentária e uso diário de medicação. Promoção de saúde bucal e seu tratamento devem ser implementados nessas instituições para reduzir a prevalência de perda dentária nesses adolescentes.

Palavras-chave Perda de dente, Cárie dentária, Adolescente, Saúde bucal 


\section{Introduction}

The adolescence is characterized to be a period of change and transition, which affects physical, sexual, cognitive, and emotional aspects ${ }^{1,2}$. It is a biological process, with a profound transformation, in the cognitive development and personality structure ${ }^{3}$. Thus, is a phase of emotional reorganization, in which conflicts arising from biological, psychical and social changes are often externalized by conduct ${ }^{2}$. Usually, the definition for age range among the adolescents is the period between 10 to 19 years of age ${ }^{3}$.

Data from the National Council of Justice survey indicate that, in 2016, 189,000 adolescents were in conflict with the law in Brazil, of which 29,794 complying sentences incarcerated. The predominant age group is 15 to 20 years. According to Brazilian Institute of Geography and Statistics (IBGE), it was estimated that these numbers increase each year. The Socio-Educational Support Foundation (FASE) is an institution from the state of Rio Grande do Sul, Brazil, responsible for social reintegration of adolescents who committed an infraction. The FASE from Passo Fundo city had approximately 1,142 teenagers in their care in 2014, of these 1,053 adolescents served their sentence inmate and 89 served their sentence in semi-liberty ${ }^{5}$. The main objective of the FASE is to approach socio-educational activities for the adolescents to be able them to be reintegrated into the society. Besides, an appropriate health care can increase the chances of successful rehabilitation ${ }^{6}$.

The institutions responsible for social reintegration usually have precarious access to health care and lower socio-economic status, making difficult to reestablish the oral health of these individuals, which have a tendency to early tooth $\operatorname{loss}^{7,8}$. This problem can implicate in several consequences in the adolescents life, such as psychological discomfort, physical pain, psychological disability, physical disability, functional limitation, handicap, and social disability ${ }^{8}$.

In Dentistry, tooth loss is considered a true outcome, and is probably the best proxy of overall oral health'. Several studies show a higher prevalence of tooth loss among different prison population $s^{10-13}$. When compared prison population with a non-prison population, prisoners have a higher number of decayed and missing teeth, but presented fewer number of filled teeth ${ }^{14}$. However, in institutionalized adolescents, there is a lack of data from prevalence of tooth loss, usually because the difficult access to this population ${ }^{15}$.
Therefore, considering that institutionalized adolescents comprise a distinct group of young people living under different conditions, the objective of this study is to analyze the prevalence of tooth loss and associated factors in this population.

\section{Material and methods}

\section{Study Design}

A cross-sectional study was conducted with male institutionalized adolescents, aged 15 to 19 years old, of the Socio-Educational Assistance Center (CASE) in the city of Passo Fundo, state of Rio Grande do Sul, Brazil. This CASE unit it is part to the FASE/RS. On December 2014, the CASE unit had 74 adolescents, of which all of them were invited to participate.

\section{Ethical Considerations}

This study received approval from the Institutional Review Board of the University of Passo Fundo (UPF). Additionally, a formal authorization was obtained by the head of FASE/RS. All the adolescents included consented to participate, and a consent form was signed, for each adolescent, by the legal responsible of the CASE unit.

\section{Operational Procedures}

Trained researchers performed the interviews individually applying structured questionnaires. The interviews comprised sociodemographical, economical, medical, behavioral and oral health self-perception variables.

All present teeth, except third molars, were evaluated with exploratory probe and plane dental mirror in a room with natural light. Two trained and calibrated examiners performed the clinical evaluation in the present study. According to the World Health Organization (WHO), Decay, Missing, Filling (DMF) Index was used to assess the teeth ${ }^{16}$. All procedures were undertaken by supervision and security provided by the CASE unit.

\section{Measurement Reproducibility}

All data collection were performed by four researchers, composed by two interviewers and two clinical examiners. Two trained and cali- 
brated examiners performed all the clinical examination. The training consisted of theoretical expositive lecture. The examiners discuss the indexes and variables that would be evaluated and defined the diagnostic criteria using several images of dental caries. Calibration was performed examining twice fifteen adolescents. These adolescents were students from a public school from Passo Fundo, with similar characteristics, such as sex and age, of the institutionalized adolescents. The interval between the exams was 15-days. An experienced examiner was considered the gold standard for the inter-examiner calibration.

The training and calibration procedures were performed until satisfactory reproducibility was obtained. The interexaminer concordance showed a kappa index of 0.74 , and the intraexaminer kappa index was 0.81 .

\section{Data Analysis}

The primary outcome was tooth loss. Prevalence was defined as the percentage of individuals presenting at least one tooth loss. The adolescents with tooth loss were described according to the use of illicit drugs, daily use of medication, such as antipsychotics, anticonvulsants, antidepressants and anxiolytics, and systemic diseases. The total number of lost teeth was described according to the type of tooth and location in the sample. The sample was dichotomized into two groups: one with no tooth loss and the other with at least one tooth loss.

The independent variables were ethnicity/ skin color (white or non-white), smoking exposure (never smokers, former smokers or smokers), daily use of medication, such as antipsychotics, anticonvulsants, antidepressants and anxiolytics (yes or no) and use of illicit drugs (yes or no). Daily use of medication was included as an independent variable, as the literature shows a worst oral health condition in individuals using daily medications ${ }^{17,18}$. Therefore, it was hypothesized that individuals using daily medication would be less motivated towards a proper oral hygiene, which might result in several diseases that would lead to tooth loss.

The access to the dentist was dichotomized (yes - those who visited the dentist within the last 12 months or no - those who did not visit the dentist in the last 12 months), toothbrushing frequency ( $\leq 3$ times/day or $>3$ times/day), tooth sensitivity when consuming cold or hot substances (yes or no) and self-reported halitosis (yes or no) were assessed.
To both questions, tooth sensitivity and self-reported halitosis, it was possible to be answered by the Likert-scale: never, rarely, sometimes, often or always. Individuals who answered never or rarely were categorized as "no", and those that answered at least sometimes were categorized as "yes". The mean and standard deviation were used to the following continuous variables: tooth loss, age, number of decayed tooth and number teeth filled.

Associations between the outcome and the independent variables were performed by chisquare, Fisher exact test or t-test for independent samples. Moreover, Poisson regression with robust variance estimation was performed to determine the association between the outcome (tooth loss) and the independent variables (demographic characteristic: age, ethnicity/skin color; behavior characteristic: smoking exposure, daily use of medication, such as antipsychotics, anticonvulsants, antidepressants and anxiolytics, use of illicit drugs, access to the dentist and toothbrushing frequency; clinical variables: number of decayed tooth, number of teeth filled, tooth sensitivity to cold or hot and self- reported halitosis). Prevalence ratios (PR) and 95\% confidence interval (CI) were estimated based on a dichotomous outcome (individuals with tooth loss). Univariate models were fitted for each independent variable and following a forward strategy, one by one of the variables with P-value $<0.20$ were incorporated into the multivariable model. Modelling was performed by sequentially including the independent variables with the lowest P-value until only those with statistical difference remained for analysis. Multicollinearity analyses among the independent variables were performed and none was observed. The multicollinearity was determined by variance inflation factor and tolerance analyses. All statistical analyses were performed in the software SPSS, version 23.0 SPPS, (SPSS, version 23.0, IBM Corp., Armonk, NY, USA).

\section{Results}

The CASE unit had 74 adolescents, of which all of them were invited to participate. The adolescent who agreed to participate were explained by the main objective of the study, and 68 were included in the present study. Therefore, the response rate was $91.89 \%$.

Table 1 summarizes the variables of interest from adolescents with tooth loss. In the CASE 
unit, $81.2 \%$ of the adolescents declared to be users of marijuana, $46.9 \%$ declared use of antipsychotics, and $9.4 \%$ had respiratory diseases (Table 1).

When obtaining the total of teeth lost, according to the type and location of the sample, it was observed that the first molars in the mandible and first molar and central incisors in the maxilla were the most frequent ones (Figure 1).

Table 2 shows the association between tooth loss and the independent variables. Prevalence of tooth loss ( $\geq 1$ teeth loss) was $47.06 \%$ (95\%CI: $34.89-59.23$ ), and the mean ( \pm standard devia-

Table 1. Adolescents with at least one tooth loss according to variables of interest.

\begin{tabular}{lr}
\hline \multicolumn{1}{c}{ Variables } & n (\%) \\
\hline Illicit drugs & $26(81.2)$ \\
Marijuana & $16(50.0)$ \\
Cocaine & $11(34.4)$ \\
Crack & $1(3.1)$ \\
Ecstasy & \\
Daily use medication & $15(46.9)$ \\
Antipsychotic & $7(21.9)$ \\
Anticonvulsant & $5(15.6)$ \\
Antidepressive & $4(12.5)$ \\
Anxiolytic & \\
Systemic Diseases & $3(9.4)$ \\
Respiration Disorders &
\end{tabular}

tion, SD) of tooth loss was $1.75 \pm 1.98$. The mean age was $17.38 \pm 1.10$ and the mean number of decayed teeth was $1.34 \pm 1.81$. Most of them declared themselves to be non-whites (65.4\%), former smokers (46.9\%), and non-users of illicit drugs $(78.1 \%)$.

The univariate model showed that no independent variable was associated with tooth loss (Table 3). However, in the multivariate model, number of decayed teeth were associated with tooth loss (Table 3). For every decayed tooth, there is approximately $14 \%$ of higher prevalence ratio (PR) of having at least one tooth lost (PR; 95\%CI: $1.138 ; 1.010-1.281$ ). Those that reported daily use of medication, such as antipsychotics, anticonvulsants, antidepressants and anxiolytics, in comparison to no users of medication, presented a higher PR to tooth loss (PR; 95\%CI: $1.815 ; 1.027$ - 3.207). The other variables did not remain associated with tooth loss (Table 3 ).

\section{Discussion}

The main objective of this study was to show the prevalence and associated factors with tooth loss in institutionalized adolescents. The most frequently missing tooth in the sample population were first molars in the mandible and first molar and central incisors in the maxilla. The prevalence of tooth loss was $47.06 \%$. Furthermore, the study found a significant association between
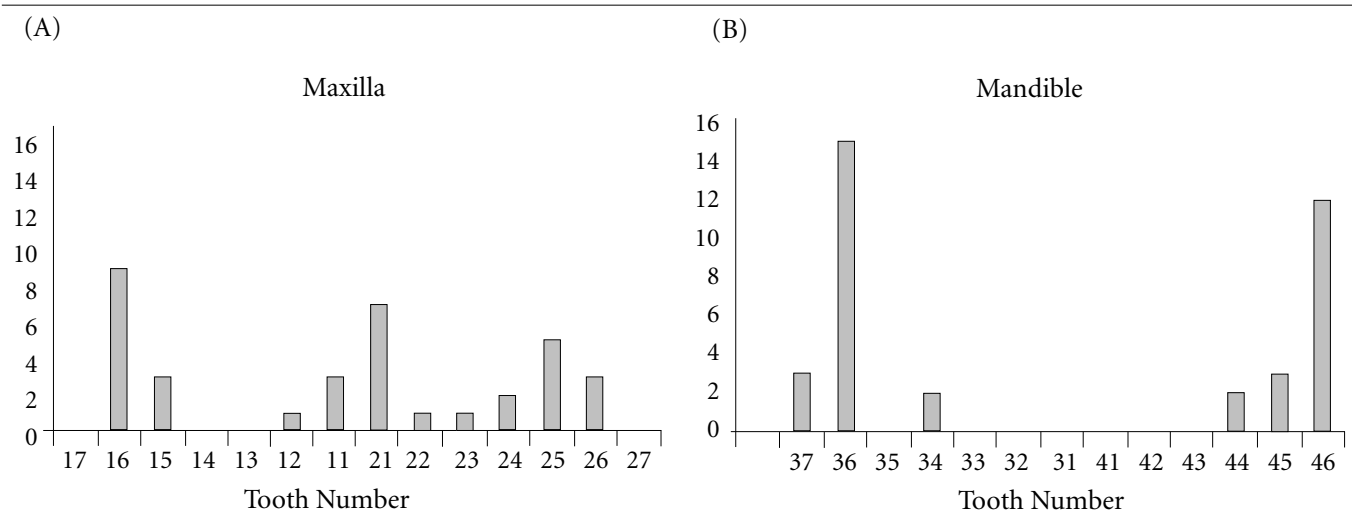

Figure 1. Total number of lost teeth according to the type and location in the sample. 
Table 2. Description characteristics of the adolescent in conflict with the law and comparison for the association between tooth loss and independent variables.

\begin{tabular}{|c|c|c|c|c|}
\hline Variables & & $\begin{array}{c}\text { Tooth loss } \\
(n=32-47.06 \%) \\
\end{array}$ & $\begin{array}{c}\text { No tooth loss } \\
(\mathrm{n}=36-52.94 \%)\end{array}$ & P-value \\
\hline Mean tooth loss & & $1.75 \pm 1.98$ & $0.0 \pm 0.0$ & - \\
\hline Age & Mean \pm SD & $17.38 \pm 1.10$ & $16.94 \pm 0.98$ & $0.095 \&$ \\
\hline Ethnicity/skin color & $\begin{array}{l}\text { White } \\
\text { Non-white }\end{array}$ & $\begin{array}{l}11(34.4) \\
21(65.4)\end{array}$ & $\begin{array}{l}11(30.6) \\
25(69.4)\end{array}$ & $0.737^{\star}$ \\
\hline Smoking exposure & $\begin{array}{l}\text { Never smokers } \\
\text { Former smokers } \\
\text { Smokers }\end{array}$ & $\begin{array}{r}10(31.3) \\
15(46.9) \\
7(21.9)\end{array}$ & $\begin{array}{r}7(19.4) \\
18(50.0) \\
11(30.6)\end{array}$ & $0.482^{\star}$ \\
\hline Daily use of medication ${ }^{a}$ & $\begin{array}{l}\text { No } \\
\text { Yes }\end{array}$ & $\begin{array}{l}10(31.3) \\
22(68.7)\end{array}$ & $\begin{array}{l}20(55.6) \\
16(44.4)\end{array}$ & $0.044^{\star}$ \\
\hline Use of illicit drugs & $\begin{array}{l}\text { Yes } \\
\text { No }\end{array}$ & $\begin{array}{r}7(21.9) \\
25(78.1)\end{array}$ & $\begin{array}{l}12(33.3) \\
24(66.7)\end{array}$ & $0.293^{*}$ \\
\hline $\begin{array}{l}\text { Access to the dentist in the last } 12 \\
\text { months }\end{array}$ & $\begin{array}{l}\text { Yes } \\
\text { No }\end{array}$ & $\begin{array}{l}18(56.3) \\
14(43.7)\end{array}$ & $\begin{array}{l}22(61.1) \\
14(38.9)\end{array}$ & $0.684^{\star}$ \\
\hline Toothbrushing frequency (per day) & $\begin{array}{l}\leq 3 \text { times } \\
>3 \text { times }\end{array}$ & $\begin{array}{r}29(90.6) \\
2(9.4)\end{array}$ & $\begin{array}{r}30(83.3) \\
6(16.7)\end{array}$ & $0.484 \#$ \\
\hline Number of decayed tooth & Mean \pm SD & $1.34 \pm 1.81$ & $0.81 \pm 1.47$ & $0.181 \&$ \\
\hline Number of teeth filled & Mean \pm SD & $0.81 \pm 1.65$ & $1.11 \pm 1.55$ & $0.444 \&$ \\
\hline $\begin{array}{l}\text { Tooth sensitivity to cold or hot } \\
\text { substances }\end{array}$ & $\begin{array}{l}\text { No } \\
\text { Yes }\end{array}$ & $\begin{array}{l}13(40.6) \\
19(59.4)\end{array}$ & $\begin{array}{r}8(22.2) \\
28(77.8)\end{array}$ & $0.101^{\star}$ \\
\hline Self-reported halitosis & $\begin{array}{l}\text { Yes } \\
\text { No }\end{array}$ & $\begin{array}{l}19(59.4) \\
13(40.6)\end{array}$ & $\begin{array}{l}16(44.4) \\
20(55.6)\end{array}$ & $0.219^{\star}$ \\
\hline
\end{tabular}

Legend: ${ }^{\star}$ Chi-square; \#Fisher exact test; \& t-test for independent samples. ${ }^{a}$ Antipsychotics, antidepressants, anxiolytics and anticonvulsant.

Source: Prepared by the authors.

Table 3. Univariate and multivariate analysis for the comparison between those with and without tooth loss.

\begin{tabular}{|c|c|c|c|c|c|}
\hline Variables & & $\begin{array}{c}\text { Prevalence ratio } \\
(95 \% \mathrm{CI})\end{array}$ & P-value & $\begin{array}{c}\text { Prevalence ratio } \\
(95 \% \mathrm{CI})\end{array}$ & P-value \\
\hline Age & & $1.226(0.972-1.546)$ & 0.085 & & \\
\hline \multirow[t]{2}{*}{ Ethnicity/skin color } & White & Ref. & 0.733 & & \\
\hline & Non-white & $0.913(0.541-1.541)$ & & & \\
\hline \multirow[t]{3}{*}{ Smoking exposure } & Never smokers & Ref. & & & \\
\hline & Former smokers & $1.169(0.587-2.329)$ & 0.657 & & \\
\hline & Smokers & $1.513(0.749-3.054)$ & 0.248 & & \\
\hline \multirow[t]{2}{*}{ Daily use of medication ${ }^{a}$} & No & Ref. & 0.059 & Ref. & 0.040 \\
\hline & Yes & $1.737(0.978-3.084)$ & & $1.815(1.027-3.207)$ & \\
\hline \multirow[t]{2}{*}{ Use of illicit drugs } & Yes & Ref. & 0.326 & & \\
\hline & No & $1.385(0.723-2.651)$ & & & \\
\hline \multirow{2}{*}{$\begin{array}{l}\text { Access to the dentist in the } \\
\text { last } 12 \text { months }\end{array}$} & Yes & Ref. & 0.682 & & \\
\hline & No & $1.111(0.671-1.840)$ & & & \\
\hline \multirow{2}{*}{$\begin{array}{l}\text { Toothbrushing frequency } \\
\text { (per day) }\end{array}$} & $\leq 3$ times & Ref. & 0.428 & & \\
\hline & $>3$ times & $0.678(0.260-1.771)$ & & & \\
\hline Number of decayed tooth & & $1.098(0.979-1.232)$ & 0.110 & $1.130(1.003-1.274)$ & 0.045 \\
\hline Number of teeth filled & & $0.930(0.743-1.165)$ & 0.530 & & \\
\hline \multirow{2}{*}{$\begin{array}{l}\text { Tooth sensitivity to cold } \\
\text { or hot substances }\end{array}$} & No & Ref. & 0.084 & & \\
\hline & Yes & $0.653(0.403-1.058)$ & & & \\
\hline \multirow[t]{2}{*}{ Self-reported halitosis } & Yes & Ref. & 0.228 & & \\
\hline & No & $0.726(0.431-1.222)$ & & & \\
\hline
\end{tabular}

${ }^{a}$ Antipsychotics, antidepressants, anxiolytics and anticonvulsant. Daily use of medication, tooth sensitivity to cold or hot substances, age and number of decayed teeth were included in the multivariate model. However, the non-significant variables were removed using a forward selection. 
tooth loss and decayed tooth, meanwhile the individuals who did daily use of medication, such as antipsychotics, anticonvulsants, antidepressants and anxiolytics, showed higher prevalence ratio of having a tooth loss.

The teeth most frequently lost in the FASE sample were first molar and upper central incisors. Most studies in Brazil show the first lower molar as the most frequently lost tooth ${ }^{19-21}$. Aida et al. $^{22}$ demonstrated that, in adolescents, the main factor associated with extraction of first molar is dental caries and the upper central incisor is periodontal disease. However, the loss of upper central incisor in this study may be attributed to trauma ${ }^{22}$.

Observational studies showed that dental trauma is a significant issue in young people ${ }^{23,24}$. Traumatic dental injuries can become an important public health problem ${ }^{25}$ not only because their prevalence can be high, ranging from $9.4 \%{ }^{26}$ to $41.6 \%{ }^{27}$, but also because they have a substantial impact on the adolescents' quality of life $^{28}$. The majority of dental injuries involve the anterior teeth ${ }^{29}$, which may lead to aesthetic and psychological problems ${ }^{24}$. Besides, to adolescents, the shame of not having a tooth is more important than the pain and the functional limitation that it causes ${ }^{30}$.

The prevalence of tooth loss in Brazilians, aged 15 to 19 years, was estimated as $8.9 \%$ according to the SB Brazil ${ }^{31}$. Another study, with adolescents in the Passo Fundo city, showed a prevalence of $21.2 \%$ of tooth $\operatorname{loss}^{32}$. However, the present study obtained a prevalence of tooth loss of $47.06 \%$ in the same age group, but in institutionalized adolescents. The prevalence of tooth loss $\geq 1$ teeth, in the prison population, ranges from $47.7 \%{ }^{33}$ to $93.9 \%{ }^{34}$, corroborating with the results found in the present study. Additionally, Boyer et al. ${ }^{35}$ showed mean tooth loss of $2.46 \pm 3.74$ in a prison population aged 17 to 53 years. Another study compared a prison population with a non-prison population and evidenced a higher number of decayed and missing teeth on the incarcerated ones ${ }^{36}$. In contrast, they found a low number of filled teeth, which may be explained by the limited access to dental care ${ }^{36}$. These data may explain the higher prevalence of tooth loss found in the present study.

Dental caries represents the most important and prevalent oral health problem in Brazil, being considered an important public health problem ${ }^{37,38}$. According SB Brazil 2010, the Brazilian prevalence of dental caries in the population aged 15 to 19 years was $35.8 \%{ }^{31}$. Epidemiologic studies showed that caries experience was an important risk indicator for tooth loss ${ }^{21,39}$. A higher level of caries is expected in young offender population due to the difficult to access the health services ${ }^{36}$. The higher levels of caries in prisoner population can be the main factor associated with tooth $\operatorname{loss}^{37,38}$, corroborating the data of the study. With the same issue, Cunningham et al. ${ }^{36}$ registered a tendency to solve oral health problems by tooth extraction. This information can explain the higher levels of tooth loss and the association between number of decay tooth showed in this study.

In response to the survey questionnaire, the FASE adolescents reported the use of antipsychotics, antidepressants, anxiolytics and anticonvulsant. More than a half of the institutionalized adolescents used daily systemic medication, and the individuals who did daily use of medication, such as antipsychotics, anticonvulsants, antidepressants and anxiolytics, showed higher PR of having tooth loss. Interestingly, some anticonvulsants have been associated with alveolar bone loss, which can result in tooth loss ${ }^{40}$. Studies indicate a relationship between antidepressants and a decrease in the salivary flow ${ }^{17,41}$, increasing the risk of dental caries ${ }^{17,41}$ and thus a future dental $\operatorname{loss}^{22}$. The use of antipsychotic drugs showed an average of tooth loss between 13.5 and $20.2^{18}$.

The present study has limitations that should be considered. The small sample size may not have been sufficient to identify other possible associations with tooth loss. The cross-sectional design constitutes a limitation, as it does not allow conclusions regarding the cause-and-effect relationship between exposure and outcome. Moreover, only male institutionalized adolescents were included, so the results cannot be extrapolated for females institutionalized adolescents. However, 96\% of the population of adolescents in conflict with the law in Brazil are men $^{4}$ and in the FASE the prevalence of men is $97 \%{ }^{4}$. In addition, the study was performed only in one institution, from one city, which restricts the sample and the external validity of the present study. Additionally, the time of the tooth loss and the time that the adolescent were institutionalized were not assessed.

The oral health situation of the young offenders from FASE shows that the health in this population is not receiving the necessary attention. Although the FASE adolescents have access to the dentist, this access is insufficient to keep them in good oral health. Since access to health is precarious, it is necessary to invest in oral health prevention campaigns, which have lower costs 
The present study makes an important contribution to knowledge of prevalence and asso-

ciated factors of tooth loss in institutionalized adolescents. The first molars and upper central incisors were the groups of most frequent tooth lost. Prevalence of tooth loss was high (47.06\%). Tooth loss was associated with decayed tooth, and daily use of medication, such as antipsychotics, anticonvulsants, antidepressants and anxiolytics was associated with higher tooth loss. Accordingly, it is necessary to provide access to oral health services to young offenders.

\section{Collaborations}

\section{References}

M Casarin: interpreted the data, wrote the manuscript, revised the literature, and approved the final version of the manuscript. WS Nolasco: interpreted the data, wrote the manuscript, revised the literature, and approved the final version of the manuscript. PRG Colussi: designed the study, helped in data collection, revised the literature, and approved the final version of the manuscript. CC Piardi: collected the data, revised the literature, and approved the final version of the manuscript. P Weidlich: helped in the study design and data analysis, revised the literature, and approved the final version of the manuscript. CK Rösing: helped in the study design and data analysis, revised the literature, and approved the final version of the manuscript. FWMG Muniz: helped in the study design, performed data analysis, interpreted the data, revised the literature, wrote the manuscript, and approved the final version of the manuscript.

\section{Acknowledgments}

This study was financed in part by the Coordenação de Aperfeiçoamento de Pessoal de Nível Superior - Brasil (CAPES) - Finance Code 001. All other funding was self-supported by the authors. The authors report no conflict of interest.

1. Slater C, Robinson AJ. Sexual health in adolescents. Clin Dermatol 2014; 32(2):189-195.

2. Yurgelun-Todd D. Emotional and cognitive changes during adolescence. Curr Opin Neurobiol 2007; 17(2):251-257.

3. Sawyer SM, Afifi RA, Bearinger LH, Blakemore SJ, Dick B, Ezeh AC, Patton GC. Adolescence: a foundation for future health. Lancet 2012; 379(9826):16301640.

4. Brasil. Justiça Brasileira. Cadastro nacional de adolescentes em conflito com a Lei [Internet]. 2016 [acessado 2019 jan 21]. Disponível em: http://www.cnj.jus.br/ sistemas/infancia-e-juventude/20531-cadastro-nacional-de-adolescentes-em-conflito-com-a-lei-cnacl.

5. Brasil. Rio Grande do Sul. Fundação de Atendimento Socio-educativo do Rio Grande do Sul [Internet]. 2018 [acessado 2019 jan 21]. Disponível em: www.fase.rs. gov.br/wp.

6. Morris R. Health Status of Incarcerated Adolescents: Implications for Juvenile Justice Decision Making. Juv Fam Court J 2004; 55(1):49-62.

7. Corraini P, Baelum V, Pannuti CM, Pustiglioni AN, Romito GA, Pustiglioni FE. Tooth loss prevalence and risk indicators in an isolated population of Brazil. Acta Odontol Scand 2009; 67(5):297-303.

8. Santillo PM, Gusmão ES, Moura C, Soares RS, Cimões R. Factors associated with tooth loss among adults in rural areas in the state of Pernambuco, Brazil. Cien Saude Colet 2014; 19(2):581-590.

9. Hujoel PP, DeRouen TA. A survey of endpoint characteristics in periodontal clinical trials published 1988-1992, and implications for future studies. J Clin Periodontol 1995; 22(5):397-407.

10. Mixson JM, Eplee HC, Feil PH, Jones JJ, Rico M. Oral health status of a federal prison population. J Public Health Dent 1990; 50(4):257-261. 
11. Conte TG. A survey of dental treatment in New Jersey Prisons. J N J Dent Assoc 1973; 44(2):10-12.

12. Shapiro S, Gallant DE, Pollack BR. Comparison of dental health profiles of two women's prisons. J Baltimore Coll Dent Surg 1971; 26(2):52-54.

13. Gilmore ND, Gluck GM. Unmet restorative treatment needs in a prison population. J Mass Dent Soc 1973; 22(4):227-230.

14. Freeman R, Richards D. Factors Associated with Accessing Prison Dental Services in Scotland: A CrossSectional Study. Dent J (Basel) 2019; 7(1):12.

15. Jones CM, Woods K, Neville J, Whittle JG. Dental health of prisoners in the north west of England in 2000: literature review and dental health survey results. Community Dent Health 2005; 22(2):113-117.

16. World Health Organization (WHO). Oral health surveys -basic methods. Geneva: WHO; 1997.

17. Kisely S, Sawyer E, Siskind D, Lalloo R. The oral health of people with anxiety and depressive disorders - a systematic review and meta-analysis. J Affect Disord 2016; 200:119-132.

18. Grinshpoon A, Zusman SP, Weizman A, Ponizovsky AM. Dental Health and the Type of Antipsychotic Treatment in Inpatients with Schizophrenia. Isr J Psychiatry Relat Sci 2015; 52(2):114-118.

19. Gjermo P, Beldi MI, Bellini HT, Martins CR. Study of tooth loss in an adolescent Brazilian population. Community Dent Oral Epidemiol 1983; 11(6):371-374.

20. Barbato PR, Peres MA. Tooth loss and associated factors in adolescents: a Brazilian population-based oral health survey. Rev Saude Publica 2009; 43(1):13-25.

21. Susin C, Haas AN, Opermann RV, Albandar JM. Tooth loss in a young population from south Brazil. $\mathrm{J} \mathrm{Pu}$ blic Health Dent 2006; 66(2):110-115.

22. Aida J, Ando Y, Akhter R, Aoyama H, Masui M, Morita M. Reasons for permanent tooth extractions in Japan. J Epidemiol 2006; 16(5):214-219.

23. Marcenes W, Al Beiruti N, Tayfour D, Issa S. Epidemiology of traumatic injuries to the permanent incisors of 9-12-year-old schoolchildren in Damascus, Syria. Endod Dent Traumatol 1999; 15(3):117-123.

24. Norton E, O'Connell AC. Traumatic dental injuries and their association with malocclusion in the primary dentition of Irish children. Dent Traumatol 2012; 28(1):81-86

25. Glendor U. Epidemiology of traumatic dental injuries--a 12 year review of the literature. Dent Traumatol 2008; 24(6):603-611.

26. Oliveira LB, Marcenes W, Ardenghi TM, Sheiham A, Bönecker M. Traumatic dental injuries and associated factors among Brazilian preschool children. Dent Traumatol 2007; 23(2):76-81.

27. Jorge KO, Moysés SJ, Ferreira EF, Ramos-Jorge ML, Zarzar PMA. Prevalence and factors associated to dental trauma in infants 1-3 years of age. Dent Traumatol 2009; 25(2):185-189.

28. Marcenes W, Alessi ON, Traebert J. Causes and prevalence of traumatic injuries to the permanent incisors of school children aged 12 years in Jaragua do Sul, Brazil. Int Dent J 2000; 50(2):87-92.

29. Sae-Lim V, Hon TH, Wing YK. Traumatic dental injuries at the Accident and Emergency Department of Singapore General Hospital. Endod Dent Traumatol 1995; 11(1):32-36
30. Silva ME, Villaça EL, Magalhães CS, Ferreira EF. Impact of tooth loss in quality of life. Cien Saude Colet 2010; 15(3):841-850.

31. Brasil. Ministério da Saúde (MS). SB Brazil Project 2010, Brazilian Oral Health Survey, Main Results. Brasília: MS; 2012.

32. Colussi P, Neves F, Muniz F, Rösing C. Tooth Loss and Associated Factors in Adolescents - Impact Of Extractions For Orthodontic Reason. Braz J Oral Sci 2018; 17:e18149.

33. Fotedar S, Chauhan A, Bhardwaj V, Manchanda K, Fotedar V. Association between oral health status and oral health-related quality of life among the prison inmate population of kanda model jail, Shimla, Himachal Pradesh, India. Indian J Public Health 2016; 60(2):150-153.

34. Rodrigues IS, Silveira IT, Pinto MS, Xavier AF, Oliveira TB, Paiva SM, Castro RD, Cavalcanti AL. Locked mouths: Tooth loss in a women's prison in northeastern Brazil. ScientificWorldJournal 2014; 2014:587469.

35. Boyer EM, Nielsen-Thompson NJ, Hill TJ. A comparison of dental caries and tooth loss for Iowa prisoners with other prison populations and dentate U.S. adults. J Dent Hyg 2002; 76(2):141-150.

36. Cunningham M, Glenn R, Field H, Jakobsen J. Dental Disease Prevalence in a Prison Population. J Public Health Dent 1995; 45:52.

37. Silveira MF, Freire RS, Nepomuceno MO, Martins AM, Marcopito LF. Tooth decay and associated factors among adolescents in the north of the State of Minas Gerais, Brazil: a hierarchical analysis. Cien Saude Colet 2015; 20(11):3351-3364.

38. Borges CM, Cascaes AM, Fischer TK, Boing AF, Peres MA, Peres KG. Dental and gingival pain and associated factors among Brazilian adolescents: an analysis of the Brazilian Oral Health Survey 2002-2003. Cad Saude Publica 2008; 24(8):1825-1834.

39. Susin C, Oppermann RV, Haugejorden O, Albandar JM. Tooth loss and associated risk indicators in an adult urban population from south Brazil. Acta Odontol Scand 2005; 63(2):85-93.

40. Cornacchio AL, Burneo JG, Aragon CE. The effects of antiepileptic drugs on oral health. J Can Dent Assoc 2011; 77:b140.

41. Friedlander AH, Norman DC. Late-life depression: psychopathology, medical interventions, and dental implications. Oral Surg Oral Med Oral Pathol Oral Radiol Endod 2002; 94(4):404-412.

Article submitted 07/10/2019

Approved 09/04/2021

Final version submitted 11/04/2021

Chief editors: Romeu Gomes, Antônio Augusto Moura da Silva 